\title{
FGF4 and INT2 Oncogenes Are Amplified and Expressed in Kaposi's Sarcoma
}

Sonja Kiuru-Kuhlefelt, M.D., Maarit Sarlomo-Rikala, M.D., Marcelo L. Larramendy, Ph.D., Maria Söderlund, Ph.D., Klaus Hedman M.D., Ph.D., Markku Miettinen, M.D., Ph.D., Sakari Knuutila, Ph.D.

Departments of Medical Genetics (SK-K, MLL, SK), Virology (MS, KH), and Pathology (MS-R), Haartman Institute, University of Helsinki and Helsinki University Central Hospital, Finland; Armed Forces Institute of Pathology, Department of Soft Tissue Pathology, Washington, DC (MM)

Kaposi's sarcoma (KS) is a vascular tumor, the pathogenesis of which has been suggested to include human herpesvirus 8 (HHV-8) as well as various cytokines and growth factors. Very little is known about cytogenetic and molecular genetic changes in KS. We studied DNA copy number changes in KS and found a recurrent gain at 11q13. We then analyzed the amplification and expression status of two known oncogenes, FGF4 and INT2, residing at 11q13. Comparative genomic hybridization, interphase fluorescence in situ hybridization with yeast artificial chromosome probes containing FGF4 and INT2, and immunoperoxidase immunostaining with anti-FGF4 and -INT2 antibodies were used on $12 \mathrm{KS}$ samples. All samples tested were shown by polymerase chain reaction to be HHV-8 positive. A recurrent gain at 11 q13 was shown by comparative genomic hybridization in 4 of 10 cases studied. Of six cases studied by interphase fluorescence in situ hybridization, four showed a 3- to 4-fold amplification with the probes containing FGF4 and INT2. Expression of FGF4 and INT2 was found in nine and three cases, respectively, of nine studied. Amplification and expression of these genes is particularly interesting in the context of oncovirus involvement, because INT2 is a homolog of mouse int2, which causes mammary carcinoma in mice when activated by integration of retrovirus mouse mammary tumor virus. This raises the question of whether HHV-8 represents an integrating oncovirus that causes amplification and activation of genomic oncogenes in humans.

Copyright () 2000 by The United States and Canadian Academy of Pathology, Inc.

VOL. 13, NO. 4, P. 433, 2000 Printed in the U.S.A.

Date of acceptance: October 6, 1999.

Address reprint requests to: Sakari Knuutila, Ph.D., Department of Medical Genetics, P.O. Box 21, (Haartmaninkatu 3, 4th Floor), FIN-00014 University of Helsinki, Helsinki, Finland; e-mail: Sakari.Knuutila@ helsinki.fi; fax 358-9-191-26788.
KEY WORDS: Comparative genomic hybridization, DNA amplification, FGF4, Human herpesvirus-8, INT2, Kaposi's sarcoma.

Mod Pathol 2000;13(4):433-437

Kaposi's sarcoma (KS) is a vascular tumor characterized by proliferation of endothelial cells and spindle cells accompanied by lymphoplasmacytic infiltration (1). In patients who are seropositive for the human immunodeficiency virus (HIV), KS is the most common malignant lesion but also occurs in patients who experience iatrogenic immunosuppression and endemically in some African and Mediterranean populations (2). Because of its often indolent course and common tendency to spontaneously regress, KS has been suggested to be a hyperplastic rather than a neoplastic process $(3,4)$. During the past few years, a $\gamma$-herpesvirus, human herpesvirus 8 (HHV-8), or Kaposi's sarcoma-associated herpesvirus, has been consistently demonstrated in HIVassociated and unassociated KS and is believed to be pathogenetically important in KS (5-8). Multiple factors have been suggested to contribute to the angioproliferation and transformation of KS cells. These include angiogenic and growth factors such as VEGF/VPF, FGFs, and so forth $(9,10)$. Very little is known about cytogenetic and molecular genetic changes in KS. To trace DNA copy number changes in KS, we applied comparative genomic hybridization (CGH) and found a recurrent gain at 11q13. Multiple genes reside in this amplicon, including two oncogenes of possibly special interest in KS: FGF4 (HSTF or K-FGF), which has originally been identified by transfection of KS DNA (11), and INT2 (FGF3), whose mouse homolog is activated by provirus insertion in murine mammary carcinogenesis. Here we have studied the potential roles of FGF4 and INT2 in KS. 


\section{MATERIALS AND METHODS}

\section{Samples}

Twelve histologically verified KSs were studied. The gender and AIDS or HIV status of the patients are shown in Table 1. All tissues were fixed in formaldehyde and embedded in paraffin and were further processed as described next.

\section{Polymerase chain reaction by HHV-8 sequence- specific primers}

HHV-8-specific DNA was amplified by polymerase chain reaction (PCR) using the forward and reverse primers $5^{\prime}$-ggagggcacgctagcttcagtg and 5'tcctcactccaatcccaatgc, respectively (modified from Muralidhar et al. [12]), that are specific for the K12 open reading frame, also known as kaposin. The kaposin gene was recently identified as an HHV-8 transforming gene (12).

Six KS samples, 10 epithelioid sarcoma samples, 1 dermatofibrosarcoma protuberans sample, and water were used as templates in the PCR after the DNA had been extracted from paraffin sections as described by Miller et al. (13) and were diluted in water 1:10 and 1:100. PCR cycles were $94^{\circ} \mathrm{C}$ for 10 min to activate the enzyme, then $30 \times 94^{\circ} \mathrm{C}$ for 15 seconds, $55^{\circ} \mathrm{C}$ for 30 seconds, and $72^{\circ} \mathrm{C}$ for 40 seconds, then $72^{\circ} \mathrm{C}$ for $5 \mathrm{~min}$ in a reaction mixture containing $200 \mu \mathrm{M}$ each dNTP, $0.6 \mu \mathrm{M}$ each primer, and 2.5 units Ampli Taq Gold polymerase in the buffer supplied by the manufacturer (Perkin Elmer Applied Biosystems, Foster City, CA).

The amplified products were separated in gel electrophoresis, transferred to nylon membrane, and hybridized to a digoxigenin-labeled probe. The probe was made by incorporation of DIG-11-dUTP (Boehringer-Mannheim, Mannheim, Germany) into the synthesized DNA strands by PCR, using the same primers and conditions as above.

\section{Comparative genomic hybridization}

Representative areas of the purest available tumor tissue were chosen from each case for CGH. Paraffin sections from these areas were cut into tubes, and DNA was extracted as described by Miller et al. (13). Ten samples yielded DNA with satisfactory strand length. CGH was performed using fluorochromes conjugated to a mixture of dCTP and dUTP for standard nick translation (14). Briefly, the tumor DNA was labeled with fluorescein isothiocyanate -dCTP and -dUTP mixture (DuPont, Boston, MA), and reference genomic DNA was labeled with Texas red -dCTP and -dUTP mixture (DuPont) by nick translation to obtain DNA fragments ranging from 600 to 2000 base pairs. The hybridization mixture consisted of $800 \mathrm{ng}$ labeled tumor DNA, $800 \mathrm{ng}$ labeled reference DNA, and $20 \mu \mathrm{g}$ COT-1 DNA in $10 \mu \mathrm{l}$ hybridization buffer ( $50 \%$ formamide, $10 \%$ dextran sulfate, $2 \times$ standard saline citrate $[\mathrm{SSC}])$. The hybridization was performed after $5 \mathrm{~min}$ denaturation at $75^{\circ} \mathrm{C}$ of the hybridization mixture and 2 min denaturation of the metaphase spread slides in $70 \%$ formamide $/ 2 \times$ SSC at $68^{\circ} \mathrm{C}$.

After $48 \mathrm{~h}$ of hybridization at $37^{\circ} \mathrm{C}$, the slides were washed three times in $50 \%$ formamide $/ 2 \times$ SSC (pH 7), twice in $2 \times$ SSC, and once in $0.1 \times$ SSC at $45^{\circ} \mathrm{C}$, followed by $2 \times$ SSC, $0.1 \mathrm{M} \mathrm{NaH}_{2} \mathrm{PO}_{4}-0.1 \mathrm{M}$ $\mathrm{Na}_{2} \mathrm{HPO}_{4}-0.1 \% \mathrm{NP} 40(\mathrm{pH}$ 8), and distilled water at room temperature for $10 \mathrm{~min}$ each. After air drying, the slides were counterstained with $4^{\prime}, 6$-diamidino2-phenylindole-dihydrochloride (Sigma, St. Louis, MO) and then mounted with an antifading medium (Vectashield, Vector Laboratories, Burlingame, CA).

TABLE 1. Summary of the CGH, FISH, Immunohistochemical Staining, and HHV-8-Specific PCR Results of 12 KS Cases

\begin{tabular}{|c|c|c|c|c|c|c|c|}
\hline \multirow{2}{*}{ Case } & \multirow{2}{*}{ Sex/HIV } & \multirow{2}{*}{$\begin{array}{l}\text { Copy Number } \\
\text { Changes }\end{array}$} & \multicolumn{2}{|c|}{ Number of FISH Signals } & \multicolumn{2}{|c|}{$\begin{array}{l}\text { Immunoreactivity of } \\
\text { Tumor Cells }\end{array}$} & \multirow{2}{*}{$\begin{array}{l}\text { HHV-8 } \\
\text { PCR }\end{array}$} \\
\hline & & & $\begin{array}{c}\text { YAC 55G7 } \\
\text { (Range) }\end{array}$ & $\begin{array}{l}\text { YAC 214D11 } \\
\text { (Range) }\end{array}$ & FGF4 & INT2 & \\
\hline 1 & $\mathrm{~F} /-$ & $+11 \mathrm{q} 13$ & $3(2-5)$ & $3(2-5)$ & - & - & NA \\
\hline 2 & $\mathrm{M} / \mathrm{HIV}$ & $+11 \mathrm{q} 13$ & NA & NA & + & - & + \\
\hline 3 & $\mathrm{M} /-$ & $+11 \mathrm{q} 13,+22$ & $3(2-5)$ & $3(2-6)$ & NA & NA & NA \\
\hline 4 & $\mathrm{M} / \mathrm{HIV}$ & $+11 q 13,+16 p$ & NA & NA & + & - & NA \\
\hline 5 & $\mathrm{~F} /-$ & $\begin{array}{l}-6 q 24 \text {-qter, +8q, } \\
-10,+16 p\end{array}$ & $3(2-5)$ & $3(2-5)$ & ++ & ++ & NA \\
\hline 6 & M/AIDS & NR & $4(2-5)$ & $4(2-6)$ & + & + & NA \\
\hline 7 & M/AIDS & NR & $4(2-6)$ & $3(2-6)$ & + & - & + \\
\hline 8 & M/AIDS & None & 2 & 2 & ++ & + & + \\
\hline 9 & $\mathrm{M} /-$ & None & NA & NA & ++ & - & + \\
\hline 10 & $\mathrm{M} /-$ & None & NA & NA & NA & NA & + \\
\hline 11 & $\mathrm{M} /-$ & None & NA & NA & NA & NA & NA \\
\hline 12 & M/AIDS & None & 2 & NR & + & - & + \\
\hline
\end{tabular}

CGH, comparative genomic hybridization; FISH, fluorescence in situ hybridization; HHV-8, human herpesvirus 8; PCR, polymerase chain reaction; KS, Kaposi's sarcoma; HIV, human immunodeficiency virus; YAC, yeast artificial chromosome; F, female; M, male; NR, unsuccessful hybridization; NA, no sample available. 


\section{Digital image analysis}

The hybridizations were analyzed using an Olympus fluorescence microscope and the ISIS digital image analysis system (MetaSystems $\mathrm{GmbH}, \mathrm{Al}-$ tlussheim, Germany) based on an integrated highsensitivity monochrome charge-coupled device camera and automated CGH analysis software. Three-color images-red for reference DNA, green for tumor DNA, and blue for counterstaining-were acquired from five to nine good quality metaphases for each sample. The green and red fluorescence intensities were calculated, and the red-to-green ratio profiles along the chromosome axis were displayed. Chromosomal regions were interpreted as overrepresented when the corresponding ratio exceeded 1.17 (gains) and as underrepresented (losses) with a ratio of less than 0.85 . The results were confirmed using $99 \%$ confidence interval.

\section{Interphase fluorescence in situ hybridization}

Two overlapping yeast artificial chromosome (YAC) clones, 55G7 and 214D11, covering the FGF4/ INT2 region at 11q13, were used as probes (15). YAC 950, which hybridizes to $11 \mathrm{p} 16$, was used as a control probe. The probes, labeled with biotin-14-dATP using standard protocols, were visualized with fluorescein isothiocyanate. The probes gave specific hybridization signals in normal metaphase preparations at the expected locations.

Interphase fluorescence in situ hybridization (FISH) was performed in six cases (Table 1) on nuclei extracted from paraffin sections as described previously (16). Paraffin-embedded reactive lymphatic tissue was used as control target. When all probes were hybridized separately on these nuclei, they showed two signals in more than $73 \%$ of the cells.

\section{Immunohistochemistry}

Formalin-fixed and paraffin-embedded KS samples were immunohistochemically evaluated with a monoclonal antibody FGF4 (dilution 1:1000) (Sigma Chemical, St. Louis, MO) and polyclonal antibody FGF3 (INT2) (dilution 1:50) (Santa Cruz Biotechnology, Santa Cruz, CA). Avidin-biotin complex immunoperoxidase technique was performed by using Elite ABC kit (Vectain, Vector Laboratories). Normal skin surrounding the tumor was used as a control.

\section{RESULTS}

\section{PCR for HHV-8}

All six KS samples tested were HHV-8 K12 positive (Table 1), yielding an expected $222 \mathrm{bp}$ fragment in gel electrophoresis, whereas all negative control samples were negative. Southern hybridization confirmed the results.

\section{$\mathrm{CGH}$}

CGH was successful in 10 of 12 cases (Table 1). Four of them (Cases 1, 2, 3, and 4) showed gains in $11 q 13$, which was the only change in two cases (1 and 2). The additional changes were gains of chromosome 22 (Case 3), 16p (Case 4), 8q, and 16p (Case 5), as well as losses of 6q24-qter and chromosome 10 (Case 5). The copy number changes are shown graphically in Fig. 1. Five cases showed no DNA copy number changes.

\section{Interphase FISH}

Interphase FISH studies were performed in seven cases (1, 3, 5, 6, 7, 8, and 12). Case 8 consistently gave two signals with both probes, and Case 12 gave two signals with 55G7 (FISH with 214D11 was not successful). Cases 1, 3, and 5 showed on average three signals with both probes; the number of signals between different cells varied from two to six. Case 6 gave on average four signals with both probes (range, 2 to 6). Case 7 gave on average four (range, 2 to 6) and three (range, 2 to 6) signals with $55 \mathrm{G7}$ and 214D11, respectively (Fig. 2). The control probe 950 gave two signals in $78 \%$ of the cells.

\section{Immunohistochemistry}

The results are summarized in Table 1. Three cases showed significant FGF4-reactivity, which was observed in at least $30 \%$ of spindle cells and endothelial cells of the KS lesions. Five additional cases showed focal or patchy reactivity in up to $10 \%$ of tumor cells. Two cases were negative. Among the non-neoplastic components, some pericytes, smooth muscle cells of the vessel walls, arrector pili smooth muscle cells, basal cells of epidermis, and occasional inflammatory cells were positive.

INT2-immunoreactivity was observed in three cases that were also positive for FGF4 in a similar manner. One of the positive cases showed strong,

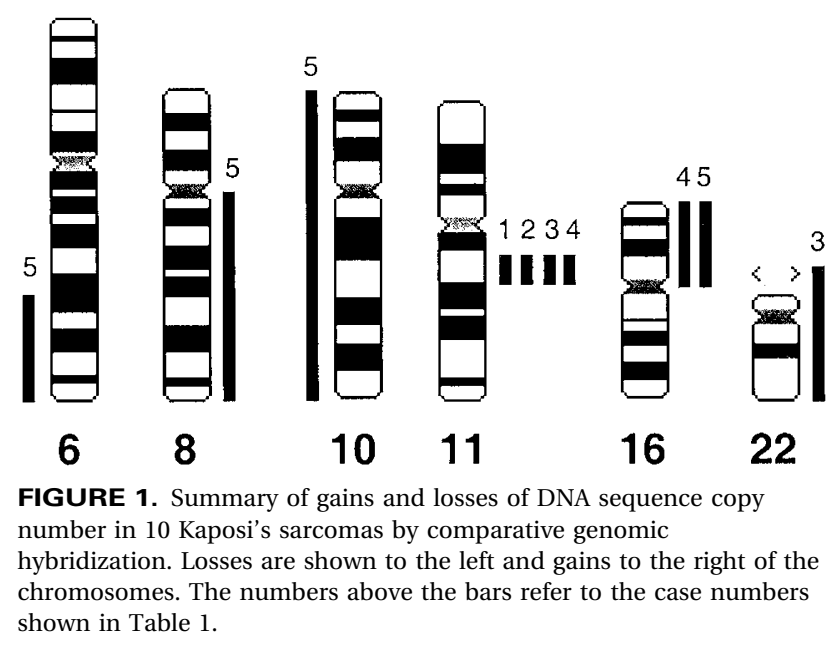




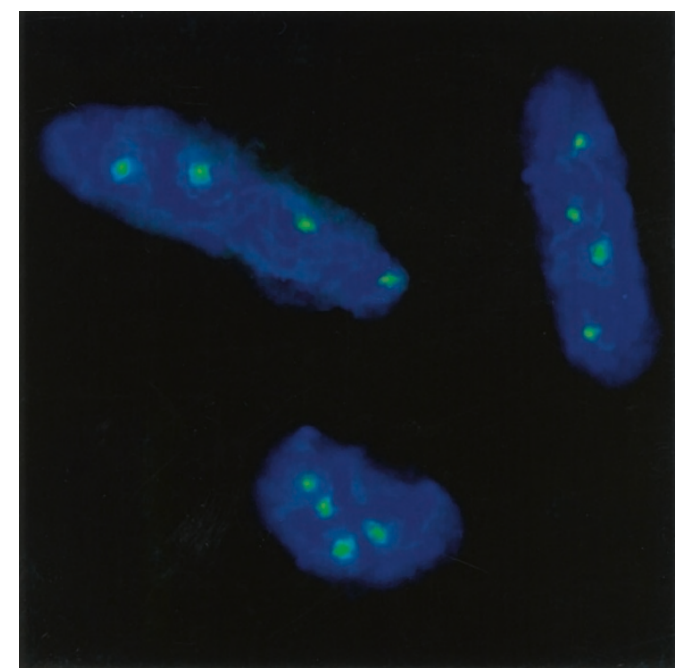

FIGURE 2. Interphase fluorescence in situ hybridization of Case 7 with probe $55 \mathrm{G} 7$. Green fluorescein isothiocyanate signals in the cells indicate a 2-fold amplification in different cells.

widespread reactivity (Fig. 3), and in two cases, up to $10 \%$ of the tumor cells were focally positive. Among the non-neoplastic components, the only ones to show positivity were occasional basal cells in the epidermis and hair shaft epithelium in one case.

\section{DISCUSSION}

In the present study, we demonstrated a DNA sequence copy number gain at 11q13, showed amplification of two probes carrying the FGF4 and INT2 genes, and indicated expression of these genes in KS. The gain at $11 \mathrm{q} 13$ is frequently observed in human malignancies, such as breast cancer, head and neck and oral squamous cell carcinomas, small cell lung cancer, and carcinomas of the urinary bladder (17). In addition to the oncogenes FGF4 and INT2, CCND1 and EMS1 have been assigned to this amplicon (18-20). The CCND1 and

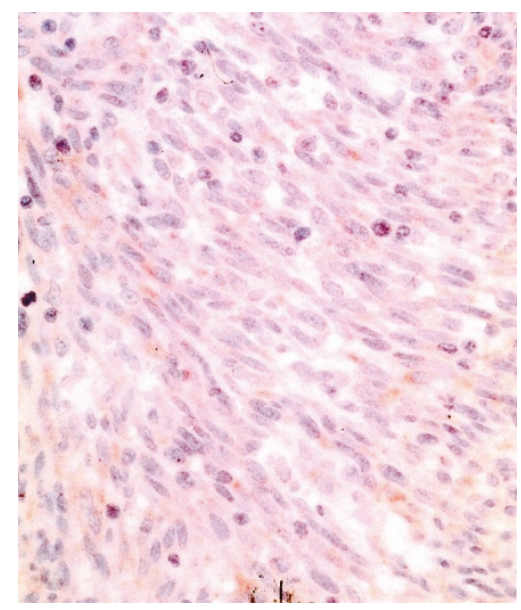

FIGURE 3. Immunohistochemical staining of Case 5 with anti-FGF4 antibody shows strong, widespread immunoreactivity.
EMS1 genes may also be amplified at the $11 \mathrm{q} 13$ gain, but the status of amplification and expression was studied only for FGF4 and INT2 because of their theoretical significance.

The absence of detectable DNA copy number changes in five KS cases may have been caused by the inevitable presence of non-neoplastic cells in the tumors. The non-neoplastic leukocytes, fibroblasts, and so forth may dilute the DNA copy number changes in tumor cells beyond the resolution of CGH. In addition, to be detected by CGH, the total amount of amplified DNA has to be at least $2 \mathrm{Mb}$; thus, a 3- to 4-fold amplification of a single gene inevitably would remain below the detection limit of CGH (21). Indeed, expression of at least FGF4 was detected in all but one case studied by immunohistochemistry. Expression was present in one case with other detectable CGH changes but gain at 11q13. This is probably an indication of the limited resolution capability of CGH; amplification was seen with both probes in this case. However, one case with a DNA copy number gain at 11q13, also shown to be amplified with both probes, failed to show immunoreactivity with either antibody. This may be caused by the lack of antigen preservation, by nonspecific staining reaction, or by other mechanisms not fully understood, leading to negative immunohistochemical staining result. In the mouse, fgft and int 2 are known to be expressed during embryogenesis $(22,23)$. Assuming the expression pattern to be similar in humans, no expression would be expected in normal adult tissues. In some samples, however, some weak positivity was seen also among occasional non-neoplastic cells. This most likely nonspecific staining is probably due to the primary fixation process.

FGF4 and INT2 belong to the fibroblast growth factor family, members of which have been suggested to be involved in the pathogenesis of KS (10, 24). Coamplification of FGF4 and INT2 has been reported in different human malignancies including melanoma, breast cancer, and oral squamous cell carcinoma, but the expression pattern varies (25-27). FGF4 was originally identified by transfection of stomach, colon cancer, and KS DNAs into NIH3T3 cells $(11,28)$. It is a potent mitogen for different mesodermal cell types, including fibroblasts and endothelial cells. INT2 is a homolog of murine mammary tumor virus integration site oncogene int2, which is activated in some mouse mammary carcinomas by integration of murine mammary tumor virus proviruses. Overexpression of either FGF4 or INT2 has been demonstrated to induce tumorigenesis in EF43 mouse cells $(29,30)$. Expression of INT2 has been reported in KS lesions, but the activation mechanism is not known (31). Our data show that not only INT2 but also FGF4, to even greater excess, is expressed in KS cells. The 
mechanisms of amplicon formation are not well understood, but our FISH results suggest gene amplification to be the probable cause of the expression, although mechanisms such as activating mutations cannot be excluded. The identification of oncogenes in KS with homology to mouse genes known to be activated by a tumor virus is intriguing, considering the recognition of HHV-8 as the causative agent of KS. Although no evidence of HHV-8 integration to the genome has been shown, this cannot be ruled out as a possible mechanism of amplification and oncogene activation in KS and needs further investigation.

Acknowledgments: This study was supported by grants from the Finnish Cancer Society and the Research Funds of Helsinki University Central Hospital. We thank Anita Ikonen for assistance with the laboratory work.

\section{REFERENCES}

1. Tappero JW, Conant MA, Wolfe SF, Berger TG. Kaposi's sarcoma. J Am Acad Dermatol 1993;28:371-95.

2. Beral V. Kaposi's sarcoma. Cancer Surv 1991;10:5-22.

3. Brooks JJ. Kaposi's sarcoma: a reversible hyperplasia. Lancet 1986;2:1309-11.

4. Costa J, Rabson AS. Generalized Kaposi's sarcoma is not a neoplasm [letter]. Lancet 1983;1:58.

5. Chang Y, Cesarman E, Pessin MS, Lee F, Culpepper J, Knowles DM, et al. Identification of herpesvirus-like DNA sequences in AIDS-associated Kaposi's sarcoma. Science 1994;266:1865-9.

6. Whitby D, Howard MR, Tenant-Flowers M, Brink NS, Copas A, Boshoff C, et al. Detection of Kaposi sarcoma associated herpesvirus in peripheral blood of HIV-infected individuals and progression to Kaposi's sarcoma. Lancet 1995;346:799802.

7. Warmuth I, Moore PS. Kaposi sarcoma, Kaposi sarcomaassociated herpesvirus, and human T-cell lymphotropic virus type 1 . What is the current evidence for causality? [editorial; comment]. Arch Dermatol 1997;133:83-5.

8. Martin JN, Ganem DE, Osmond DH, Page-Shafer KA, Macrae D, Kedes DH. Sexual transmission and the natural history of human herpesvirus 8 infection. N Engl J Med 1998;338:948-54.

9. Samaniego F, Markham PD, Gendelman R, Watanabe Y, Kao $\mathrm{V}$, Kowalski K, et al. Vascular endothelial growth factor and basic fibroblast growth factor present in Kaposi's sarcoma (KS) are induced by inflammatory cytokines and synergize to promote vascular permeability and KS lesion development. Am J Pathol 1998;152:1433-43.

10. Li JJ, Huang YQ, Moscatelli D, Nicolaides A, Zhang WC, Friedman-Kien AE. Expression of fibroblast growth factors and their receptors in acquired immunodeficiency syndrome-associated Kaposi sarcoma tissue and derived cells. Cancer 1993;72:2253-9.

11. Delli Bovi P, Basilico C. Isolation of a rearranged human transforming gene following transfection of Kaposi sarcoma DNA. Proc Natl Acad Sci 1987;84:5660-4.

12. Muralidhar S, Pumfery AM, Hassani M, Sadaie MR, Azumi N, Kishishita $\mathrm{M}$, et al. Identification of kaposin (open reading frame K12) as a human herpesvirus 8 (Kaposi's sarcomaassociated herpesvirus) transforming gene. J Virol 1998;72: 4980-8.
13. Miller SA, Dykes DD, Polesky HF. A simple salting out procedure for extracting DNA from human nucleated cells. Nucleic Acids Res 1988;16:1215.

14. El-Rifai W, Larramendy ML, Björkqvist A-M, Hemmer S, Knuutila S. Optimization of comparative genomic hybridization using fluorochrome conjugated to dCTP and dUTP nucleotides. Lab Invest 1997;77:699-700.

15. Courseaux A, Szepetowski P, Fernandes M, Serizet C, Kawaguchi Y, Grosgeorge J, et al. Framework YAC contig anchored into a 3.2-Mb high-resolution physical map in proximal 11q13. Genomics 1996;40:13-23.

16. Monni O, Zhu Y, Franssila K, Oinonen R, Höglund P, Elonen E, et al. Molecular characterization of deletion at 11q22.123.3 in mantle cell lymphoma. Br J Haematol 1999;104:665-71.

17. Knuutila S, Björkqvist A-M, Autio K, Tarkkanen M, Wolf M, Monni O, et al. DNA copy number amplifications in human neoplasms: review of comparative genomic hybridization studies. Am J Pathol 1998;152:1107-23.

18. Casey G, Smith R, McGillivray D, Peters G, Dickson C. Characterization and chromosome assignment of the human homolog of int-2, a potential proto-oncogene. Mol Cell Biol 1986;6:502-10.

19. Huebner K, Ferrari AC, Delli Bovi P, Croce CM, Basilico C. The FGF-related oncogene, K-FGF, maps to human chromosome region 11q13, possibly near int-2. Oncogene Res 1988; 3:263-70.

20. Schuuring E, Verhoeven E, Mooi WJ, Michalides RJ. Identification and cloning of two overexpressed genes, U21B31/ PRAD1 and EMS1, within the amplified chromosome 11q13 region in human carcinomas. Oncogene 1992;7:355-61.

21. Kallioniemi O-P, Kallioniemi A, Piper J, Isola J, Waldman FM, Gray JW, et al. Optimizing comparative genomic hybridization for analysis of DNA sequence copy number changes in solid tumors. Genes Chromosomes Cancer 1994;10:231-43.

22. Hebert JM, Basilico C, Goldfarb M, Haub O, Martin GR. Isolation of cDNAs encoding four mouse FGF family members and characterization of their expression patterns during embryogenesis. Dev Biol 1990;138:454-63.

23. Represa J, Leon Y, Miner C, Giraldez F. The int-2 protooncogene is responsible for induction of the inner ear. Nature 1991;353:561-3.

24. Schwartz RA. Kaposi's sarcoma: advances and perspectives. J Am Acad Dermatol 1996;34:804-14.

25. Adelaide J, Mattei MG, Marics I, Raybaud F, Planche J, De Lapeyriere $\mathrm{O}$, et al. Chromosomal localization of the hst oncogene and its co-amplification with the int. 2 oncogene in a human melanoma. Oncogene 1988;2:413-6.

26. Ali IU, Merlo G, Callahan R, Lidereau R. The amplification unit on chromosome 11q13 in aggressive primary human breast tumors entails the bcl-1, int-2 and hst loci. Oncogene 1989;4:89-92.

27. Lese CM, Rossie KM, Appel BN, Reddy JK, Johnson JT, Myers EN, et al. Visualization of INT2 and HST1 amplification in oral squamous cell carcinomas. Genes Chromosomes Cancer 1995;12:288-95.

28. Sakamoto H, Mori M, Taira M, Yoshida T, Matsukawa S, Shimizu K, et al. Transforming gene from human stomach cancers and a noncancerous portion of stomach mucosa. Proc Natl Acad Sci U S A 1986;83:3997-4001.

29. Hajitou A, Calberg-Bacq CM. Fibroblast growth factor 3 is tumorigenic for mouse mammary cells orthotopically implanted in nude mice. Int J Cancer 1995;63:702-9.

30. Deroanne CF, Hajitou A, Calberg-Bacq CM, Nusgens BV, Lapiere CM. Angiogenesis by fibroblast growth factor 4 is mediated through an autocrine up-regulation of vascular endothelial growth factor expression. Cancer Res 1997;57:5590-7.

31. Huang YQ, Li JJ, Moscatelli D, Basilico C, Nicolaides A, Zhang WG, et al. Expression of int-2 oncogene in Kaposi's sarcoma lesions. J Clin Invest 1993;91:1191-7. 